\title{
Monetary Policy in the Founder Countries of ASEAN
}

\section{DÁNIEL MOLNÁR, DIÁNA HORVÁTH \& GÁBOR REGŐS}

\begin{abstract}
In this paper, we examined the monetary policy systems of the ASEAN-5 countries (Indonesia, Malaysia, Philippines, Singapore, and Thailand) in order to assess the countries' readiness for a higher level of integration, a monetary union. We found that these countries successfully adopted many of the best practices of the developed countries, especially transparency which is important in anchoring market expectations. Furthermore, we did not find any significant differences in the five countries regarding inflation volatility and level, which could have been explained by the different monetary policy regimes employed. On the monetary union prospects, we found that inflation rates and exchange rates in the five countries showed strong connections, which is necessary to avoid the need for nominal exchange rate adjustments. On the other hand, the economies are far from the required harmonization, which resulted in different monetary policy reactions to the same shocks. In addition, the independence of the monetary policy has not been achieved in most ASEAN-5 countries, which can become a huge obstacle in the establishment of a supranational authority conducting common monetary policy in a monetary union.
\end{abstract}

Keywords: ASEAN, monetary policy, monetary union

\section{Introduction}

Any economic integration can be described by its depth. The literature (e.g. Balassa, 2013) describes five different levels of integration: free trade, customs union, common market, economic union (or single market), and complete economic integration. Through the different levels of integration, more and more restrictions are lifted among the countries participating in the integration. From the abolishment of tariffs in free trade to complete economic integration where the unification of monetary, fiscal, social policies are achieved, with the establishment of a supranational authority whose decisions overwrite those of the member states. However, even in this breakdown, each level can be divided into more stages as we can see in the case of the European Union or the Eurozone, where the monetary integration is almost finished, but the political, social, and fiscal integration are still in their earlier stages. The ASEAN (Association of Southeast Asian Nations) integration is still far from this point in the integration process. According to the 
ASEAN Community Vision 2025, the advancement of the single market agenda is "through enhanced commitments in trade in goods, and through an effective resolution of non-tariff barriers; deeper integration in trade in services; and a more seamless movement of investment, skilled labour, business persons, and capital' (ASEAN Community Vision 2025, 2015), so a common market is still only in the goals of the integration.

Thus, it is clear that the ASEAN integration is still decades away from even an economic union, not to mention a complete economic integration. However, even at this level of integration, it is important to examine the readiness of the ASEAN countries (Indonesia, Malaysia, Philippines, Singapore, and Thailand) to deepen the integration. Before a monetary union is introduced, it is fundamental that the participating countries have a well-functioning monetary policy system because it can help the economic development through many channels. Moreover, the synchronization of the monetary policies can reduce the exchange rate volatility among member states, which, in return, helps to strengthen economic relations, thus, forwarding the economic integration without the need to give up the independent monetary policy - an important tool in any crisis management.

In the literature, Vatsa, Sharma, and Basnet (2010) researched the same issue, specifically focusing on currency exchange rate co-movements. According to the literature, highly correlated business cycles are one of the necessary conditions for a higher level of economic or monetary union. They found that - except for Indonesia - the other member states of ASEAN exhibit co-movement both in the long-run and in the short-run which indicates monetary policy coordination among these countries. The reason behind this is that the four countries demonstrated a very similar response to the examined crisis (Latin American and Asian Financial Crisis). Taylor, in his 2018 presentation, assessed the monetary policy and the development of interest rates in ASEAN countries since the Asian Financial Crisis (International Monetary Fund [IMF], 2016) and the exposure of their monetary policy to the decisions of other national banks, in particular the Federal Reserve (Fed). He concluded that with its interest rate decisions, the Fed has a significant impact on the economic performance of ASEAN countries, mainly through the exchange rate, so the decisions of the region's national banks follow the Fed. Dau and Sethapramote (2019) reached the same result. They analysed the fiscal and monetary policy spillovers in ASEAN countries. The authors found that these spillovers are significant for all of the 5 countries, and in case of external spillovers, other East Asian countries have a greater effect on ASEAN countries than the advanced Western countries ${ }^{1}$. Expansionary monetary spillovers have a negative effect on ASEAN countries' real GDP, which implies that the exchange rate transmission channel is very important in the ASEAN economies. The authors concluded that the policy coordination among ASEAN countries as well as at the regional and global level is necessary and important.

In this paper, we focus on the monetary policy of the ASEAN-5 countries: we examine the possibility of a monetary union amongst them. In the existing literature, the focus was only on the exchange rates, while the evolution of the inflation was neglected, which is similarly important in the optimum currency area 
(OCA) theory (Mongelli, 2008). To fill this gap, we conducted a compact analysis of the monetary policy of the ASEAN-5 countries to determine their readiness for a monetary union.

The paper is organized as follows: Section 2 describes the inflation-targeting systems, its requirements, and its advantages against other monetary policy regimes. Section 3 introduces the monetary policy systems in the ASEAN-5 countries with critical remarks in comparison with the developed countries' practice. Section 4 evaluates the monetary systems in the five countries, through the evolution of the base rate, the inflation rate, and the exchange rate. Finally, Section 5 concludes the paper.

\section{Monetary Policy and Inflation Targeting}

The most commonly used monetary policy system, also considered as best practice, is the inflation targeting strategy. According to Svensson (2010), it is the most flexible and resilient monetary policy regime, which was already tested in a crisis. The central banks realised a long time ago that the most effective way they can support sustainable long-term economic growth is through the stabilization of the price level. However, inflation targeting is more than just an announcement of the inflation target. Mishkin (2002) published a set of "rules" which must be followed for the effectiveness of the system:

1. Public announcement of a medium-term numerical target for inflation

2. Institutional commitment to price stability as the primary goal of monetary policy, to which other goals are subordinated

3. Information-inclusive strategy in which many variables are used for deciding the set of policy instruments

4. Increased transparency of the monetary policy strategy through communication

5. Increased accountability of the central bank for attaining its inflation objectives

However, studies show mixed results on the effectiveness of the inflation targeting system in comparison with other monetary regimes. de Carvalho Filho (2011), found that during the crisis of 2008, countries using the inflation targeting system performed better than those implying different regimes. They were able to lower nominal and real interest rates much faster, thus, they were less likely to experience deflation scares. In addition, their currencies experienced real depreciations without a rise in perception of risk by markets, which, in turn, may help to raise external demand. Other researchers (Mishkin and Schmindt-Hebbel, 2007), found that the fall in inflation (both in level and volatility), interest rate, and output volatility was a worldwide trend and was not exclusive to inflation targeting countries. Furthermore, they found that inflation persistence is lower for inflation targeters, and, in their countries, inflation expectations are more anchored, thus they react less to shocks. 
Other alternatives to the inflation targeting system are money growth targeting and exchange rate targeting systems. The main problem with the former is that there is no exact connection between money growth and inflation, thus the practical experiences show this cannot guarantee the stabilization of the inflation. While the exchange rate targeting system is exposed to speculative attacks and increased international capital flows (Svensson, 2010). However, even if a central bank does not use inflation targeting regime, the points set above in relation to the employed regime can help raise the effectiveness of the given system.

\section{Monetary Policy Systems in the ASEAN-5 Countries}

In this chapter, we examine monetary policy systems of the ASEAN-5 countries. We concentrate on the main objective of the central bank in each country, its main instruments, and its relationship to the government. In the case of each central bank, we evaluate monetary systems in relation to the points presented in the previous chapter. We used the publicly available information on each central bank's website, the acts governing them, and the monetary policy statements.

\section{Indonesia}

Bank Indonesia's (BI) goal is to achieve and maintain the stability of the local currency, the rupiah. The stability of the currency is defined by the stability of prices, thus the central bank adopted the inflation targeting framework in 2005. Furthermore, Bank Indonesia, although adhering to a free-floating exchange rate system, also operates exchange rate policy to minimise its volatility.

The inflation target in Indonesia is set by the Government with the Decree of the Minister of Finance for a 3-year period. This helps to anchor market actors' inflation expectations for the midterm. The current inflation target is $3 \%$ with a $2 \%$ wide symmetric target band. However, for the year 2021 , there is not any established inflation target yet, which, considering the delayed-effect of any monetary policy action due to transmission, can significantly lower the effectiveness of the monetary policy in Indonesia.

In the past, the inflation target and the target band changed a lot, almost yearly. For the first two years (2001 and 2002), the BI set a band for the target which was changed for 2003 to a target point with a tolerance band. This system is active since then but the target was reduced significantly. From the continuous changes in the inflation target, one can assume that the decision-makers tried to set an achievable goal, instead of one that would help the economy in the long term and stick to it to anchor inflation expectations. This helped them to conduct a much more flexible monetary policy, while a stricter target would have needed a constantly strict monetary policy. 
Figure $1^{2}$

Evolution of Bank Indonesia's inflation target and target band

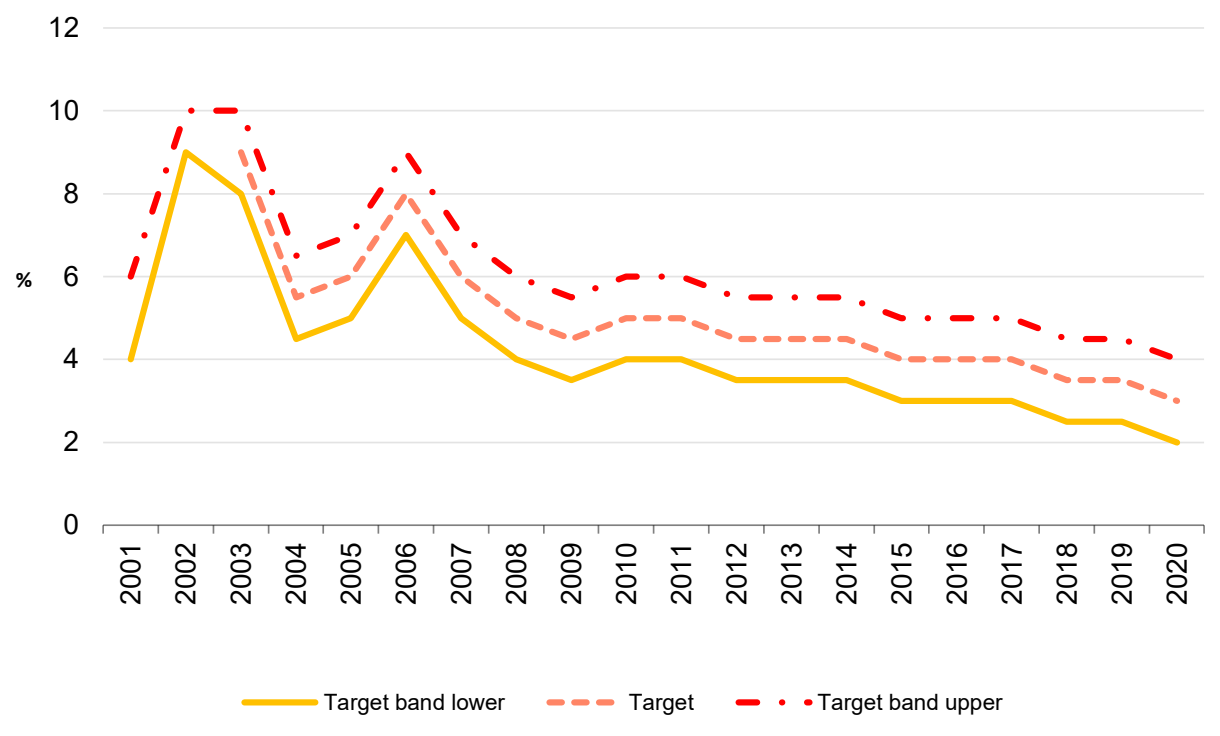

The BI operates as an independent state institution, which guarantees its freedom from interference by any external party, including the Government. However, in article 7 of Act No. 3 of 2004 concerning Bank Indonesia (2009), it is stated that the central bank shall conduct monetary policy taking into account the general economic policies of the government. This somewhat contradicts the independence of the central bank in conducting monetary policy to achieve the inflation target. This stipulation appears in many other acts concerning central bank policy but mostly as a secondary goal, e.g. for the European Central Bank, clearly subordinated to inflation targeting.

The main monetary policy tool of Bank Indonesia is a 7-Day (Reverse) Repo Rate which was introduced in August 2016. Through this, the central bank can affect the interbank money market. Besides this, the Bl employs standing facilities to limit the volatility of overnight interbank rates and provide or absorb liquidity if necessary. Furthermore, Bank Indonesia conducts open market operations to absorb or provide liquidity to the money market to maintain equilibrium.

Another important aspect of the monetary policy in Indonesia is the stance concerning fiscal policy. There are regular meetings between Bank Indonesia and the Government to coordinate policy actions. While this practice is common even in developed countries, Bank Indonesia, due to Covid-19, decided to purchase Government Securities in the primary market from June 2020. This is monetary financing which is forbidden in developed countries, and for a good reason. 
Monetary financing reduces budgetary discipline and compromises the primary goal of the monetary policy, the achievement of price stability (Korencsi, Lakatos \& Pulai, 2013). This is somewhat circumvented with the quantitative easing measures which are conducted on the secondary market, and the ECB uses restrictions on the purchases. However, in the case of $\mathrm{BI}$, the purchases occur in the primary market, which can lower the credibility of the monetary policy in achieving its target.

\section{Malaysia}

The principal objective of the Bank Negara Malaysia (BNM) is to maintain monetary and financial stability to support the growth of the economy (Central Bank of Malaysia Act 2009). The role of the Bank is to formulate a monetary policy which, according to Article 22(1), "serves the interests of the country with the primary objective of maintaining price stability giving due regard to the developments in the economy". In the case of financial stability, the central bank should pursue developing a sound, resilient, progressive, and diversified financial sector, which in return, can help the real economy. Although the BNM target is to maintain price stability, it does not employ an inflation targeting system, there is no stated inflation target in Malaysia.

The main instrument of Bank Negara Malaysia is the Overnight Policy Rate (OPR), which is the minimum interest rate in the interbank market charged amongst banks when they borrow liquidity from each other. Furthermore, the BNM operates standing facilities to minimise volatility in the interbank market, they are set 0.25 basis points above (lending) and below (deposit) the policy rate. However, the principal monetary instrument is the uncollateralised direct borrowing through open tender, the maturity of which can range from overnight to six months. Besides this, the BNM executes repo transactions - to absorb from and provide liquidity to banks for eligible securities up to one year - foreign currency (FX) swaps, and auctions of Monetary Notes and Interbank Bills.

Although the act behind Bank Negara Malaysia states that the bank shall formulate its monetary policy and actions autonomously and without external influence, the stated connection with the Malaysian Government contradicts this independence. According to the act, the Central Bank shall keep the Finance Minister informed of the conducted monetary policy relating to its principal objects. In case there is a difference of opinion between the Minister and the Bank relating to its principal objects, the Minister and the Bank shall endeavour to reach an agreement. If it is not possible, the Cabinet determines the policy to adopt by the Central Bank.

One more aspect of the act governing Bank Negara Malaysia is worth mentioning. The act allows monetary financing to the government, on market terms, if there are some temporary deficiencies of budget revenues. Although both the time and the value of this financing are capped in the act, this may undermine the independence and the credibility of the Central Bank in achieving its objective. However, this kind of safeguard is not unprecedented in developed countries. The Bank of England uses a similar system in the form of the Ways and Means (W\&M) facility to smooth government cash flows in case of short-term disruption. 


\section{Philippines}

The primary objective of Bangko Sentral ng Pilipinas (BSP) is to maintain price stability to achieve balanced and sustainable economic growth (Republic Act No. 7653 1993, 2019). To achieve this goal, the BSP has operated inflation targeting since 2002. One uniqueness of the system in the Philippines is that the inflation target is set by the Development Budget Coordination Committee (DBCC), a Governmental inter-agency together with the BSP. In contrast, ECB's or the Fed's target is set by the central bank itself.

The inflation targeting system has changed significantly since its introduction in 2002. Between 2002 and 2007, the BSP operated a 1\% wide band target, which was replaced by a point target with a tolerance band in 2008, which is still in effect. The inflation target changed a lot, too. The target band in the first years of the system was gradually lowered but then, in 2009 and 2010, it was raised to ease the monetary policy's stand in response to the crisis. After that, the inflation target became stable. The only change occurred in 2015 when the government decided to lower the midpoint to $3 \%$ while keeping the $2 \%$ wide symmetrical band. Another difference in the BSP's inflation targeting system in comparison with the Bank Indonesia's is that the target is set for two years in advance. This can greatly help to anchor inflation expectations, thus helping the bank to achieve its target.

Figure $2^{3}$

Evolution of Central Bank of the Philippines' inflation target and target band ${ }^{4}$

7

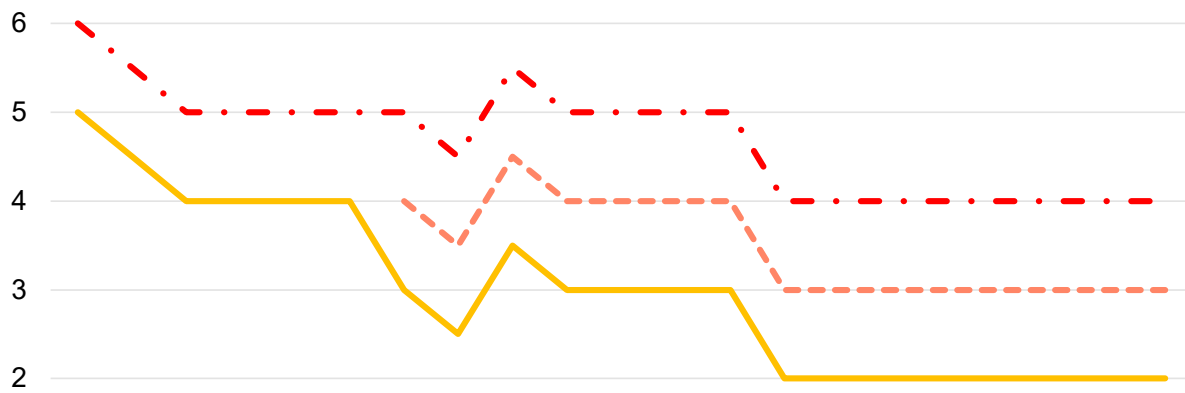

1

0

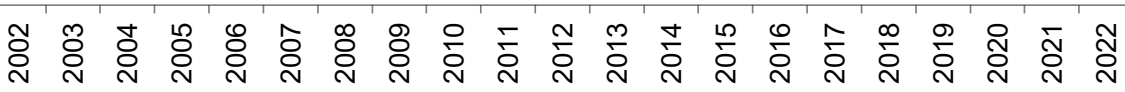
Target band lower $\quad--$ Target $\quad-$ - Target band upper 
The primary instrument of the BSP is the overnight reverse repurchase rate (RRP). Through the RRP, the BSP buys or sells government securities to banks to have an expansionary or contractionary effect on liquidity. In addition, the BSP operates overnight standing facilities to counter liquidity shortage and excess on an overnight basis. It also operates a term deposit facility (TDF) to absorb liquidity through deposit auction on 7, 14, and 28-day basis, and sets the reserve requirements for banks.

Although the act states that the BSP should operate as an independent and accountable institution, it is worth mentioning that one member of the seven in the Monetary Board is always a member of the Cabinet. However, in decision-making, majority rule is applied, meaning the Board can decide against the Cabinet member's decision therefore allowing independence in practice in the monetary policy.

\section{Singapore}

The monetary policy practice of the Monetary Authority of Singapore (MAS) greatly differs from those of the other four ASEAN countries. This is because it is centred on the exchange rate, instead of the inflation target. The final goal of the MAS is still price stability conducive to sustainable growth to the economy (Monetary Authority of Singapore Act 1999, 2018), but the central bank plans to achieve this through the stability of the Singapore dollar. The main reason behind the different monetary policy setting is that Singapore is an open economy where the value of the export and import together exceeds $310 \%$ of the GDP, while in the other two open ASEAN-5 countries (Malaysia and Thailand) it is only 123.1 and $110.3 \%$ respectively, according to the World Bank's data for 2019. Indonesia and the Philippines are considered relatively closed economies because their combined trade does not reach the value of the GDP (only 37.3 and $68.6 \%$ respectively). Because of this, the MAS can affect the economic process much more through the exchange rate than through interest rate policies. On the other hand, with exchange rate targeting, the MAS gives up direct control over domestic interest rates, which is determined by capital movements, and money supply.

Based on the applied monetary policy system, Singapore is the most prepared country of the five for a monetary union. This is because one of the last steps in the creation of a monetary union is the pegging of the exchange rate between the participating countries, through which they give up their independent monetary policy (see the ERM II system in the case of the Eurozone). However, the MAS's differs from other exchange rate targeting monetary regimes (like in Bulgaria) because the Singapore dollar is not pegged to a single currency but a trade-weighted basket of currencies (S\$NEER). While in the case of a monetary union, the Singapore dollar would be pegged to the other participating countries' currencies, meaning it would have to use a floating exchange rate system against the rest of the world. 
Figure $3^{5}$

The evolution of the S\$NEER (Jan 1999=100)

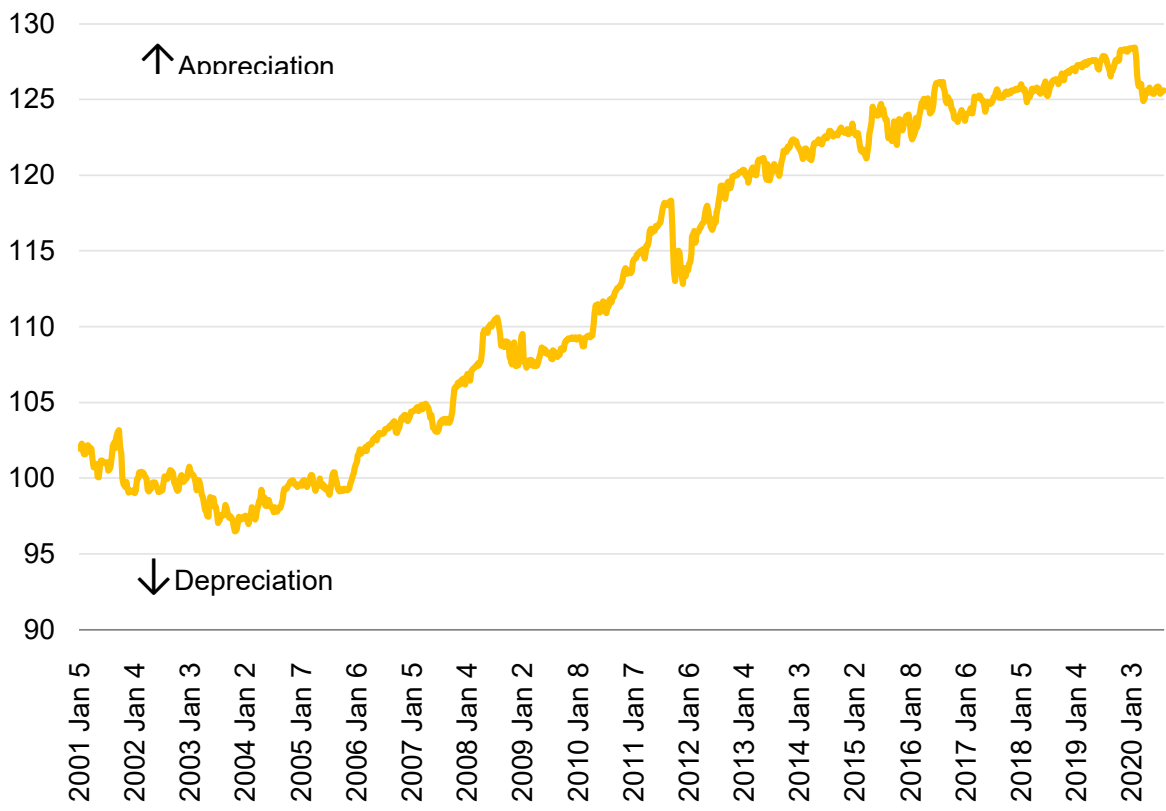

However, the MAS does not set a point target but a policy band within, the exchange rate is allowed to fluctuate, which gives flexibility in conducting monetary policy. The bank announces the policy band to the market semi-annually, and reviews the composition of the basket. After each review (in April and October), a Monetary Policy Statement is released about the stance of the monetary policy in Singapore. However, this underlines the transparency of the monetary policy in Singapore as most central banks issue statements monthly or bimonthly to anchor market expectations and reduce uncertainty.

The main instrument of the MAS are the foreign exchange operations. With these operations the authority can keep the exchange rate in the policy band. At the same time, despite the exchange rate system, the MAS operates standing facilities to ease liquidity problems overnight, both in the Singapore dollar and the renminbi, and intraday in the Singapore dollar.

There is one more aspect in which the Monetary Authority of Singapore differs from the others presented above. The act governing the institution does not state that the MAS is independent, just that, according to Article 4(2), it "acts as the central bank of Singapore, conduct monetary policy, issue currency, oversee payment systems and serve as banker to and financial agent of the Government'. 


\section{Thailand}

The Bank of Thailand (BOT) has employed a flexible inflation targeting system since 2000 , with the main objective of maintaining price stability. The act controlling the monetary policy in Thailand (Bank of Thailand Act 1942, 2018) states, the BOT objectives consist of maintaining monetary stability, financial institution system stability, and payment systems stability. To achieve these objectives, the act states furthermore, that the Monetary Policy Board shall determine the targets of the monetary policy for every year with a corporative agreement from the Cabinet. This gives significant flexibility to the BOT to change the monetary policy system if the economic conditions require it. Despite this, the Bank of Thailand did not change the regime since the start of inflation targeting in 2000 but the target and target range change regularly.

In the first 9 years, the BOT determined a band for the core inflation ${ }^{6}$ between 0 and $3.5 \%$. The use of core inflation is logical in the sense that it excludes products that are highly volatile, and thus, enables them to affect the underlying inflation process through the central bank's instruments. However, the lower band of the target range was 0 , which is dangerous in the sense that undershooting the target would cause deflation which can be a self-stimulating process, and lead to a recession. To avoid the possibility of deflation, in 2009, the BOT narrowed the target band to $0.5-3.0 \%$. The next change in the target came in 2015 when firstly, the target was changed to headline inflation instead of core inflation. Secondly, a new point target was set at $2.5 \%$ with a $3 \%$ symmetric band. The reason behind the change to the headline inflation was that it reflects the change in the cost of living much more. The BOT reasoned that setting a point target sends a clearer message to the economic actors and signals the monetary policy's stand better. The next change came in the target for 2020 when the point target was abolished and a 1-3\% target band was established. These changes until 2020 can be seen as a learning curve to a developed inflation targeting system, but the regular changes can have an adverse effect on the economy through uncertainty which can undermine economic planning.

In addition, the Bank of Thailand adopted a managed-float exchange rate system, meaning the Thai baht is allowed to move through market forces, but in case of excess volatility, the BOT might intervene, which can become inconsistent with the inflation targeting system.

To achieve the monetary policy targets, the BOT sets reserve requirements, conducts open market operations (bilateral repurchases, issuance of bills and bonds, purchases/sales of public sector debt securities), and applies standing facilities (deposit and lending). In this instance, the practice of the Bank of Thailand does not differ from the one used in most central banks. The main policy rate refers to the conducted bilateral repurchase (repo) transactions from 1 day up to 6 months.

Similar to the MAS, the act governing the Bank of Thailand does not state that the institution is independent, only that it is a juristic person which is a state agency, and that the Governor shall be independent in the management and administration of the BOT. However, the Code of Conduct for Members of the Monetary Policy Committee states, in the first point, that they must act independently in expressing opinions and 
making decisions, upholding the benefits to the overall economy. Despite this, the BOT in practice can work as an independent institution but the absence of this in the act is unusual, compared to developed central banks.

Figure 4

Evolution of Bank of Thailand's inflation target and target band ${ }^{7}$

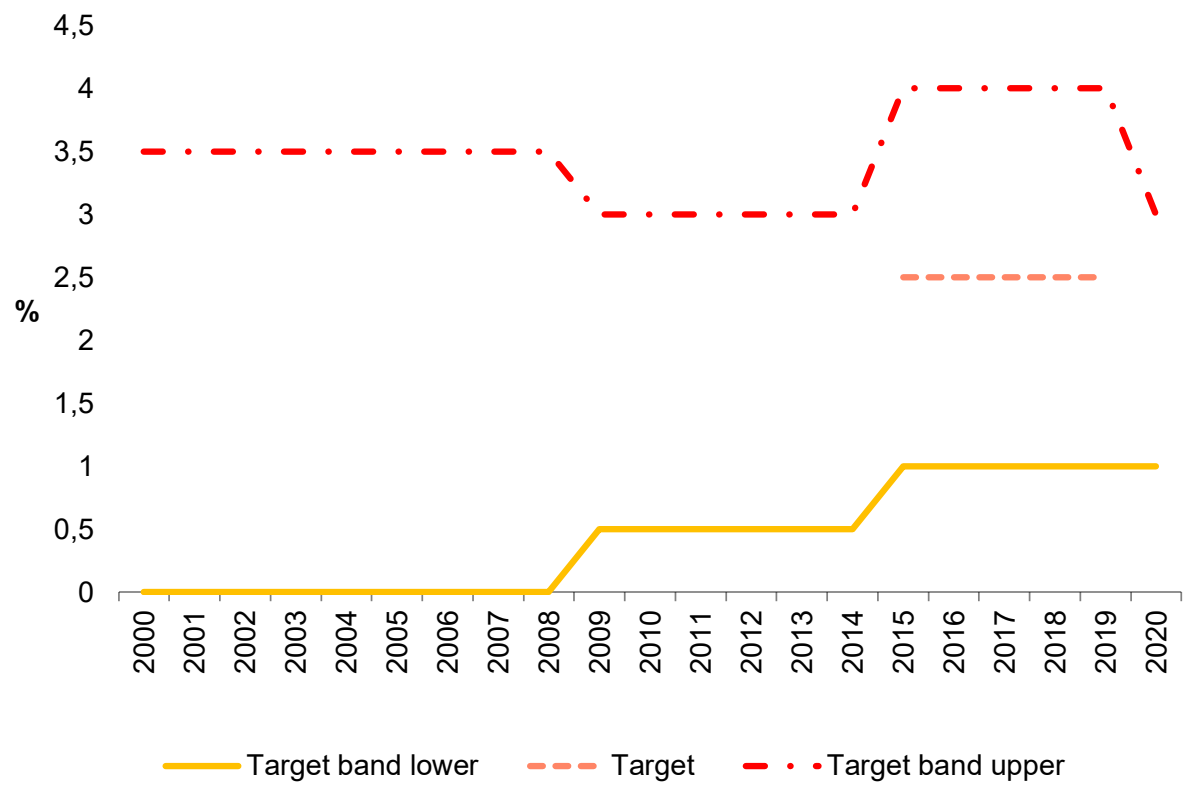

\section{Results of the Monetary Policy}

In this chapter, we examine the monetary policy of the ASEAN-5 countries regarding three factors. Firstly, we overview the base rate of the countries to compare the reactions of the monetary policy to different shocks that occurred in recent years. Secondly, we analyse the inflation process as the main objective of each central bank, and thirdly, the evolution of the exchange rate. We will evaluate the data relative to each ASEAN-5 country and concerning the requirements of a monetary union.

\section{Base rate}

The policy rates or base rates differed significantly in the five countries in the examined period. The lowest rate was recorded in Singapore, which can be explained by the fundamentally different monetary policy system. As we explained earlier, the MAS does not control the interest rate in Singapore; it is determined by capital movements and money supply, thus it is more exposed to international shocks, which can be seen in the path of the repo rate. The rate was close to zero until around 2015 when 
the Fed concluded its asset purchase program. However, the rate did not increase significantly until the middle of 2017 when the Fed announced its normalization plan to gradually reduce its securities holdings. The increase in interest rate ended in the second half of 2019 when the Federal Reserve ended its balance sheet wind down. ${ }^{8}$

In the case of Indonesia, the Bl's 7-day (Reverse) Repo Rate was only introduced in 2016 to strengthen the monetary operations. After the introduction, Bank Indonesia was able to reduce its rate until 2018, despite the Fed's interest rate hikes and balance sheet normalization plans. However, in 2018, due to the Fed Fund Rate (FFR) hike and the increasing risk in the global financial market, Bank Indonesia had to raise significantly its interest rate. The central bank was able to reduce its rate and ease monetary conditions only in 2019 , when the Fed decided to lower its policy rate.

In the last examined period (2018-2019), the Bangko Sentral ng Pilipinas conducted a similar monetary policy as Bank Indonesia. The BSP started to raise its interest rate in May 2018, a couple of days earlier than Bank Indonesia. The Monetary Board's statement explained the step with the inflationary processes and the normalization of the monetary policy in the advanced economies. After that, the BSP raised the interest rate roughly at the same time as Bank Indonesia, and overall to the same extent (175 basis points). In 2019, the BSP, earlier than Bank Indonesia, was able to reduce its policy rate, due to weaker global economic prospects. After that, the two central banks' policy rates were reduced similarly. This co-movement shows that the two economies had a similar reaction to the external shocks, which needed similar monetary policy actions.

Figure 5

Evolution of policy rates in the ASEAN-5 countries $^{9}$

7

6

5

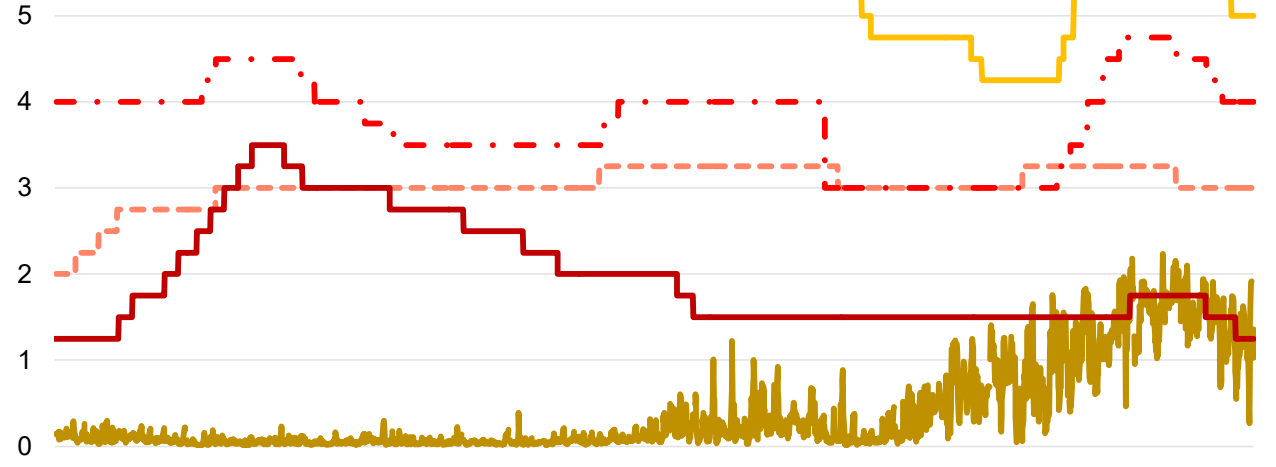

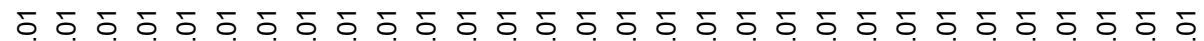
ப் ம்

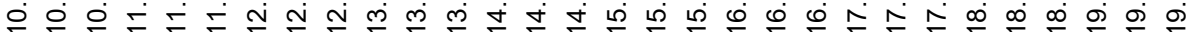

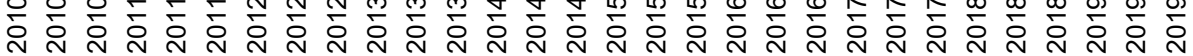

Indonesia - - - Malaysia - - The Philippines — Singapore —Thailand 
In the case of the Bank of Thailand and Bank Negara Malaysia, there was not such a big monetary policy action to the shocks of 2018 . The BNM raised its interest rate only at the beginning of 2018, but it was a pre-emptive measure to normalize monetary conditions. After that, due to the resilience of the domestic financial markets, there was not any need to change the monetary conditions. The BOT only raised its policy rate at the end of 2018 , as the need for accommodative monetary policy reduced. The BNM reduced its interest rate in 2019 , roughly at the same time as the BSP. This was due to the downside risks to global growth, according to the MPC's statement. The BOT reduced its policy rate later, only in the second half of 2019. The explanation of the decision was that a more accommodative monetary policy would help economic growth and the rise of inflation toward the target. This shows that these two central banks reacted to the same shock as the $\mathrm{BI}$ and the BSP (albeit to a smaller extent).

In examining the whole period, we can see that the Bank Negara Malaysia and the Bangko Sentral ng Pilipinas reacted similarly to different shocks in more than one instance. Both raised the interest rate in the first half of 2011 and in the summer of 2014 due to inflation pressure from energy prices in both cases. In the case of the Bank of Thailand, in these instances, there was not any monetary decision that could be connected.

These small case studies show that, although in some instances the monetary policies of the ASEAN- 5 countries react similarly to different external shocks, the economies are far from the necessary harmonization which is required for the unification of monetary policies in a monetary union.

\section{Inflation}

The inflation rate showed sizeable volatility in the ASEAN-5 countries in the last 20 years. Considering the whole period, the prices grew to the greatest extent in Indonesia, on average $6.6 \%$ per year, while the average inflation rate was only $1.6 \%$ in Singapore. This means the Monetary Authority of Singapore was able to achieve the lowest inflation rate, even with a greatly different monetary policy system. However, in Singapore, there were three years $(2002,2015,2016)$ when they registered deflation, the decrease in prices, which can become a self-stimulating process and reduce growth. The only other country that faced deflation from the ASEAN-5 was Thailand in 2009 and 2015, which can be partly explained by the very low inflation target. The other three countries registered average inflation rate between Singapore's and Indonesia's: in the Philippines 3.8, in Malaysia 2.2, and in Thailand $2.0 \%$ on average. This, however, shows that the Central Bank of Malaysia, without an inflation targeting regime, was able to achieve similar inflation rates to their counterparts in the two countries. Another mentionable trend in the ASEAN-5 countries is that the inflation-targeting countries faced a decrease in inflation rates if we compare the data from 2000-2009 to 2010-2019. Meanwhile, Malaysia and Singapore achieved similar, low rates in the two periods. The explanation behind this can be twofold. On the one hand, it is possible that through the inflation targeting 
system they were able to achieve low inflation levels. On the other hand, due to the effect of the crisis in 2008, the world-leading economies (the USA and European Union) faced lower levels of inflation rates, which, through trade, can affect the price process in the ASEAN countries.

The correlations between the different ASEAN-5 countries show a moderate positive connection (between 0.4 and 0.6 ). From this, there are only three outliers: the correlations between Thailand and the Philippines and between Thailand and Singapore show a strong positive connection (between 0.6 and 0.8 ), while the one between Indonesia and Singapore shows a very weak positive connection (between 0 and 0.2). Based on this, we can state that there are similar processes that affect the inflationary environment in ASEAN-5 countries. The similarities of inflation rates are an important factor for the establishment of a monetary union, according to Mongelli (2008), because it reduces the need for nominal exchange rate adjustments.

Figure 6

Inflation rate in the ASEAN-5 countries ${ }^{10}$

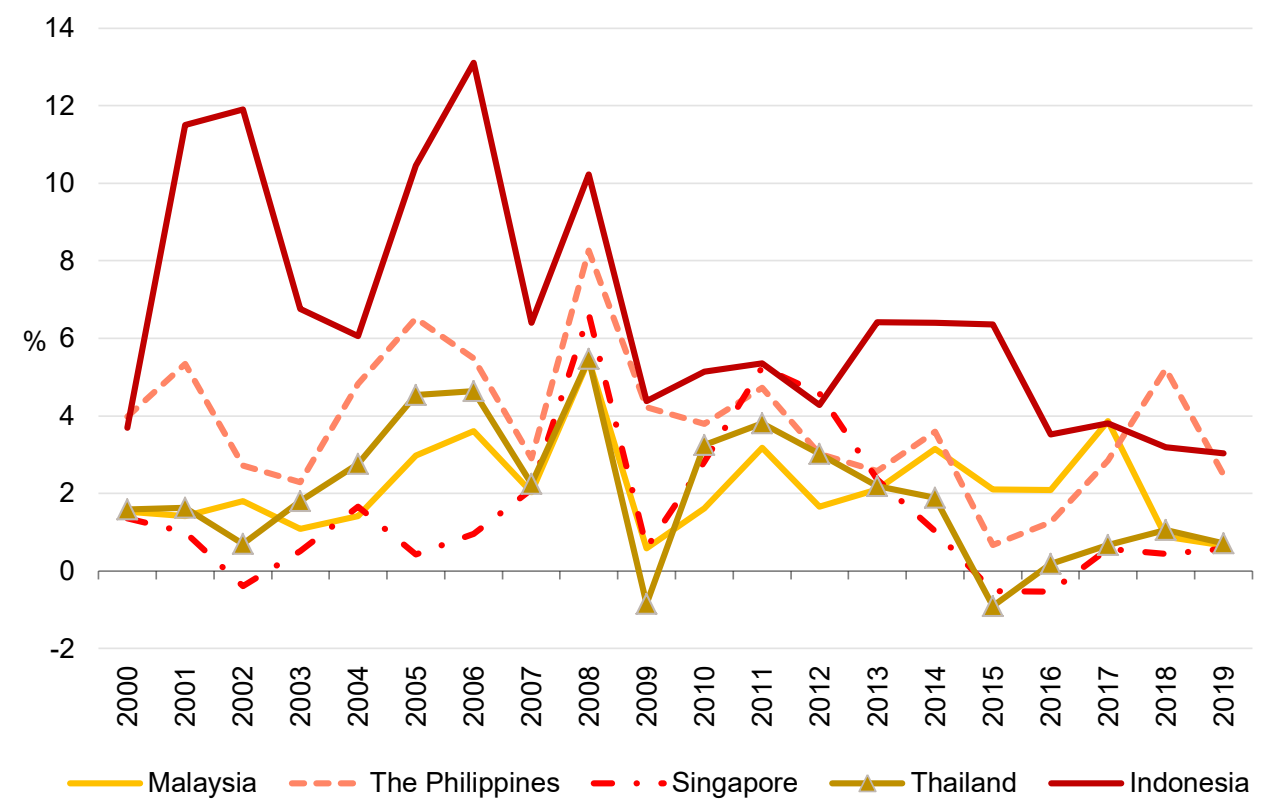

It is imperative to examine the inflation process of the inflation-targeting countries in relation to the announced inflation target for each year. In the case of the Philippines, the inflation rate was out of the central bank's target range in 10 years since 2002, the establishment of the inflation targeting system. The average difference (in absolute terms) from the mid-point of the target range was $2-4 \%$ points. Considering that after the first 6 years in the regime, the target band was widened from $1 \%$ to $2 \%$, this difference is fairly significant. 
In Thailand, the inflation rate was out of the target band in only 5 years from 2000 to $2019 .{ }^{11}$ To compare this to the Philippines, one must consider that the target range in Thailand was always wider: 3.5\% points between 2000 and 2008, $2.5 \%$ points between 2009 and 2014, and 3\% points after 2015. The average difference from the mid-point of the target band was a little smaller than in the Philippines, at $2.2 \%$ points. Furthermore, four of the five deviations happened after the change of the policy target in 2015, meaning the BOT was much more successful in affecting the underlying, persistent inflation process (core inflation) than in the headline inflation.

Similar to the BSP, the inflation in Indonesia between 2001 and 2019 was only in the $2 \%$ wide target band for half the time. However, the absolute difference was the largest in Indonesia, on average $3.5 \%$ points, meaning a very volatile inflation process in the country and a less successful monetary stabilization policy.

\section{Exchange Rate}

In the evaluation of the monetary policy in the ASEAN-5 countries, it is worth examining the evolution of the exchange rate. Mostly because the MAS uses an exchange targeting system, but because an interest rate policy has a great effect on the exchange rate too, it is imperative to examine it in other regimes. To get comparable data, we used daily exchange rates for each ASEAN-5 countries against the dollar from the start of 2010 to the end of 2019. The use of the exchange rate against the dollar offers another advantage; the effect of different external shocks on the region can be measured as well.

Considering the whole examined period, the Indonesian rupiah depreciated the most against the dollar, by more than $47.3 \%$, while the Malaysian ringgit depreciated by 19.5 and the Philippine peso by $9.6 \%$. In contrast, the Thai baht and the Singapore dollar appreciated against the dollar by 10.7 and $4.1 \%$ respectively.

However, not only the path of the exchange rate matters but also its volatility. To get comparable data, we used the relative standard deviation (RSD) which measures the ratio of the standard deviation to the mean. From the five currencies, the Singapore dollar was the least volatile between 2010 and 2019, the value of the RSD was $4.7 \%$. While for the second least volatile, the Thai baht, it was $5.5 \%$. The Philippine peso has shown a bigger volatility, $8.1 \%$, but it can still be considered somewhat stable. On the other hand, the Malaysian ringgit's $13.9 \%$ and the Indonesian rupiah's $17.9 \%$ relative standard deviation show a much more volatile path in the exchange rate. The stability of the Singapore dollar was expected, considering the exchange rate targeting monetary policy, but it is clear that, even with a different monetary system, similar stability can be achieved. At the same time, the relative stability of the Thai baht can be explained by the employed managed-float exchange rate regime.

The correlation between the exchange rates of the ASEAN-5 countries' currencies against the dollar shows a strong (between 0.6 and 0.8 ) or a very strong positive (above 0.8 ) connection in most cases. The only two exceptions 
are between the Indonesian rupiah and the Thai baht (0.57), and between the Thai baht and the Philippine peso (0.36). This shows that external shocks have a similar effect on the ASEAN-5 countries. This is a good sign for the monetary union because if external shocks have a similar effect on the countries participating in it, then uniformization of the monetary policy would have a less unfavourable effect.

Figure 7

Evolution of the exchange rate against the dollar in ASEAN $-5^{12}$

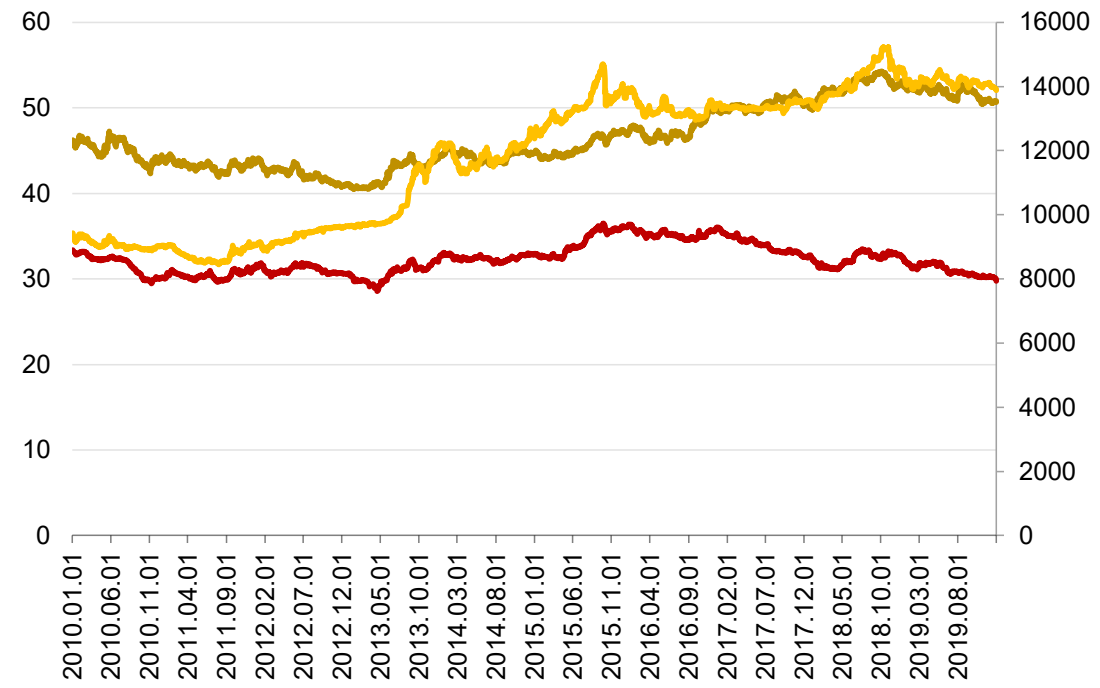

The Philippines Thailand _ _ Indonesia (right axis)

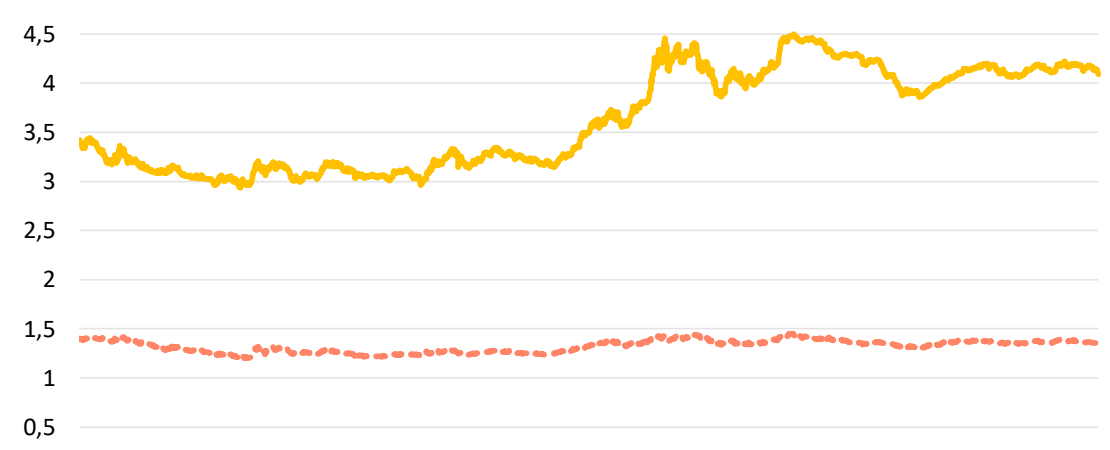

0

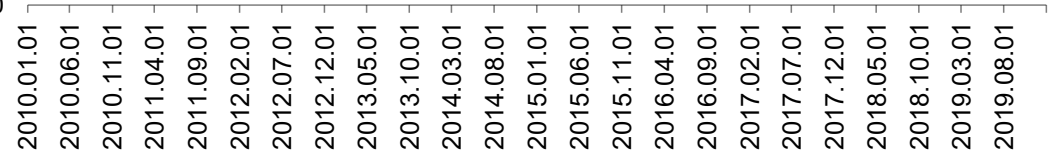

Malaysia - - Singapore 


\section{Conclusions}

In examining the monetary policy practice of the ASEAN-5 countries, we found that they adopted many of the best practices of the developed countries. The central banks work transparently, which can help to anchor market expectations, thus strengthening the monetary policy to achieve its target. However, there are many differences in the monetary policies of the five countries. Only three of them (Indonesia, the Philippines, Thailand) adopted the inflation targeting system. The other two (Malaysia and Singapore), in the case of inflation volatility and level, achieved a similar result in the long run with a different monetary policy regime. There is only one aspect of the monetary policy which has a long way to go for the ASEAN-5 countries. That is, the basic requirement of the independence of their central banks is not yet achieved; the governments have the power by law to affect the monetary policy which can reduce its effectiveness.

Our main objective was to examine the readiness of the ASEAN-5 countries for a monetary union in regard to their monetary policy practice. In some aspects, the five countries are on the right path to establishing a monetary union: their inflation rates and exchange rates show a strong connection which is necessary to avoid the need for nominal exchange rate adjustments. On the other hand, the economies are far from the required harmonization. Thus, the monetary policy in each country must react differently to the same external shock. In addition, the lack of independence in the monetary policy poses a threat to the monetary union. In a monetary union, the leaders of the participating countries must agree on a supranational authority which must conduct monetary policy independently, and in the interests of the whole union. However, in the case of some ASEAN countries, the separation of the fiscal and monetary policy, which could raise the effectiveness of the latter, has not yet happened.

\section{Bibliography}

Act No. 3 of 2004 concerning Bank Indonesia. (2009, October 5). Retrieved from https://www.bi.go.id/en/tentang-bi/uu-bi/Documents/UU32004_Engl.pdf

Association of Southeast Asian Nations. (2015). ASEAN Community Vision 2025. Retrieved from https://www.asean.org/storage/images/2015/November/aecpage/ASEAN-Community-Vision-2025.pdf [Accessed 25 August 2020]

Balassa, B. (2013). The theory of economic integration (Routledge revivals). Routledge.

Bangko Sentral ng Pilipinas. (2020). About the Bank. Retrieved from https://www. bsp.gov.ph/SitePages/AboutTheBank/AboutTheBank.aspx

Bank Indonesia. (2020). Monetary. Retrieved from https://www.bi.go.id/en/moneter/ Contents/Default.aspx

Bank Negara Malaysia. (2020). About the Bank. Retrieved from https://www.bnm. gov.my/index.php?ch=en_about\&pg=en_intro\&lang=en 
Bank of Thailand. (2020). About BOT. Retrieved from https://www.bot.or.th/English/ AboutBOT/Pages/default.aspx

Bank of Thailand Act B.E. 2485. (2018, October 12). Retrieved from https://www.bot. or.th/English/AboutBOT/LawsAndRegulations/SiteAssets/Law_E01_Bot.pdf

Central Bank of Malaysia Act 2009. (2009, November 25). Retrieved from https://www.bnm.gov.my/index.php?ch=en_legislation\&pg=en_legislation_ act\&ac $=486 \&$ full $=1$ \&lang $=$ en

de Carvalho Filho, I. E. (2011). 28 Months Later: How Inflation Targeters Outperformed Their Peers in the Great Recession. The BE Journal of Macroeconomics: 11(1).

Dau, T. M. L., \& Sethapramote, Y. (2019). Measuring Fiscal and Monetary Policies Spillovers in ASEAN. DLSU Business \& Economics Review, 28(2), 2019.

International Monetary Fund (2016). ASEAN-5 cluster report -Evolution of monetary policy frameworks. Retrieved from https://www.imf.org/external/p5ubs/ft/ scr/2016/cr16176.pdf [Accessed 17 August 2020]

Korencsi, A., Lakatos, M., \& Pulai, G. (2013). Regulation on the prohibition on monetary financing-obligations and opportunities. MNB Bulletin (discontinued), 8 (Special), 91-97.

Mishkin, F. S. (2002). Inflation Targeting. In: Snowdon, B. \& Vane, H. R. (Eds.), An Encyclopedia of Macroeconomics (pp. 361-365). Cheltenham, UK: Edward Elgar Publishing Limited.

Mishkin, F. S., \& Schmidt-Hebbel, K. (2007). Does inflation targeting make a difference? (No. w12876). National Bureau of Economic Research.

Monetary Authority of Singapore. (2020). Who we are. Retrieved from https://www. mas.gov.sg/who-we-are

Monetary Authority of Singapore Act. (2018, October 29). Retrieved from https://sso. agc.gov.sg/Act/MASA1970

Mongelli, F. P. (2008). European economic and monetary integration, and the optimum currency area theory (No. 302). Directorate General Economic and Financial Affairs (DG ECFIN), European Commission.

Punzi, M. T., \& Chantapacdepong, P. (2019). Spillover Effects of Unconventional Monetary Policy in Asia and the Pacific Region. Macroeconomic Shocks and Unconventional Monetary Policy: Impacts on Emerging Markets, 182.

Republic Act No. 7653 or the New Central Bank Act. (2019, February 14). Retrieved from https://www.bsp.gov.ph/Pages/AboutTheBank/SealCharterAndHistory/ BSPCharter/New_Central_Bank_Act.pdf

Svensson, L. E. (2010). Inflation targeting. In Friedman, B. M. \& Woodford, M. (Eds.), Handbook of monetary economics (Vol. 3, pp. 1237-1302). Elsevier.

Taylor, J. B. (2018). Design and Implementation of Monetary Policy Frameworks in ASEAN Countries. High-level peer-to-peer forum organised by IMF's Institute of Capacity Development and Asia-Pacific Department. Retrieved from https:// www.imfsti.org/wp-content/uploads/2018/10/Keynote-Design-ImplementationMon-Policy-ASEAN.pdf [Accessed 26 August 2020] 
Vatsa, P., Sharma, S. C., \& Basnet, H. C. (2010). Monetary policy synchronization in ASEAN-5 region: an exchange rate perspective. In Southern Economic Association Meetings, November, Atlanta.

\section{Endnotes}

1 Western countries included Australia, Euro Area, Japan, United Kingdom, and U.S.

2 Source: Bank Indonesia

3 Source: Central Bank of the Philippines

4 Source: Central Bank of the Philippines

5 Source: Monetary Authority of Singapore

6 Consumer price index (CPI) that excludes fresh food and energy prices

7 Source: Bank of Thailand

8 On the effect of the Fed's nonconventional monetary in Asia and the Pacific, see Punzi and Chantapacdepong (2019)

9 Source: Reuters Datastream. In the case of Singapore, the Singapore Dollar Domestic Interest Rate

10 Source: World Bank

11 Until 2015, we compared the target range to the core inflation.

12 Source: Reuters Datastream 